\title{
Microbial metal resistance and metabolism across dynamic landscapes: high-throughput environmental microbiology
}

\section{[version 1; peer review: 2 approved]}

\author{
Hans Carlson ${ }^{1}$, Adam Deutschbauer ${ }^{1}$, John Coates (iD) 2 \\ ${ }^{1}$ Environmental Genomics and Systems Biology, Lawrence Berkeley National Lab, Berkeley, CA, USA \\ ${ }^{2}$ Department of Plant and Microbial Biology, University of California, Berkeley, CA, USA
}

V1 First published: 29 Jun 2017, 6(F1000 Faculty Rev):1026
https://doi.org/10.12688/f1000research.10986.1

Latest published: 29 Jun 2017, 6(F1000 Faculty Rev):1026

https://doi.org/10.12688/f1000research.10986.1

\section{Abstract}

Multidimensional gradients of inorganic compounds influence microbial activity in diverse pristine and anthropogenically perturbed environments. Here, we suggest that high-throughput cultivation and genetics can be systematically applied to generate quantitative models linking gene function, microbial community activity, and geochemical parameters. Metal resistance determinants represent a uniquely universal set of parameters around which to study and evaluate microbial fitness because they represent a record of the environment in which all microbial life evolved. By cultivating microbial isolates and enrichments in laboratory gradients of inorganic ions, we can generate quantitative predictions of limits on microbial range in the environment, obtain more accurate gene annotations, and identify useful strategies for predicting and engineering the trajectory of natural ecosystems.

\section{Keywords}

microbial activity, inorganic compounds, metal-metabolism interactions

\author{
Open Peer Review \\ Approval Status \\ 1 \\ 2 \\ version 1 \\ 29 Jun 2017 \\ Faculty Reviews are review articles written by the \\ prestigious Members of Faculty Opinions. The \\ articles are commissioned and peer reviewed \\ before publication to ensure that the final, \\ published version is comprehensive and \\ accessible. The reviewers who approved the final \\ version are listed with their names and \\ affiliations. \\ 1. Bin Cao, Nanyang Technological University, \\ Singapore, Singapore \\ 2. David Emerson, Bigelow Laboratory for \\ Ocean Sciences, East Boothbay, USA
}

Any comments on the article can be found at the end of the article. 
Corresponding author: Hans Carlson (hkcarlson@lbl.gov)

Competing interests: The authors declare that they have no competing interests.

Grant information: This work was funded by the UC Berkeley Energy Biosciences Institute and ENIGMA. ENIGMA is a Scientific Focus Area Program supported by the U. S. Department of Energy, Office of Science, Office of Biological and Environmental Research and Genomics:GTL Foundational Science, through contract DE-AC02-05CH11231 between Lawrence Berkeley National Laboratory and the U. S. Department of Energy.

The funders had no role in study design, data collection and analysis, decision to publish, or preparation of the manuscript.

Copyright: $\odot 2017$ Carlson $\mathrm{H}$ et al. This is an open access article distributed under the terms of the Creative Commons Attribution License, which permits unrestricted use, distribution, and reproduction in any medium, provided the original work is properly cited.

How to cite this article: Carlson $\mathrm{H}$, Deutschbauer A and Coates J. Microbial metal resistance and metabolism across dynamic landscapes: high-throughput environmental microbiology [version 1; peer review: 2 approved] F1000Research 2017, 6(F1000 Faculty Rev):1026 https://doi.org/10.12688/f1000research.10986.1

First published: 29 Jun 2017, 6(F1000 Faculty Rev):1026 https://doi.org/10.12688/f1000research.10986.1 


\section{Life, the universe and everything}

In the book, The Hitchhiker's Guide to the Galaxy, the Earth is described as "a computer of such infinite and subtle complexity that organic life itself shall form part of its operational matrix". Understanding the workings of the Earth as a deterministic computational entity remains a tantalizing object, and characterizing the relationship between organic life and the rest of the "operational matrix" (that is, inorganic geochemistry) is a central theme in the environmental sciences. Although careful studies have yielded insights into how physical and chemical laws influence microbial fitness and function in response to some environmental parameters, a major challenge lies in scaling laboratory experiments to landscape-wide predictions of gene and microbial fitness (Figure 1).

\section{Recontextualizing environmental isolates through} high-throughput microbial physiology and genetics

Great strides have been made in our ability to characterize the molecular composition of matter on Earth-from elemental analyses of sediments ${ }^{2,3}$ and structural characterization of natural organics ${ }^{4}$ to 'omics measurements of gene and protein content of natural environmental communities ${ }^{5,6}$. Technological advances in computation, data storage, and analytical tools enable this revolution. Alongside these advances is a similar, though often overlooked, revolution in robotics and laboratory automation. High-throughput cultivation in microtiter plates is possible both aerobically and anaerobically, and plate readers can be used to monitor optical density or metabolites using colorimetric assays ${ }^{7,8}$. It is also possible to fill microplates with arrays of compounds or serially diluted solutions to simultaneously evaluate the influence of hundreds to tens of thousands of parameters (for example, small-molecule libraries, inorganic ions, carbon sources, or other nutrients) on microbial growth kinetics and metabolism? ${ }^{7}$. Additionally, recent advances in high-throughput genetics can be leveraged (in microbial isolates) to rapidly identify genetic determinants important for fitness in a given growth condition ${ }^{9-11}$ (Figure 2). Importantly, high-throughput assays can be used to quantitatively measure growth and respiratory activity of microbial cultures to define the fitness of a given microbial respiratory metabolism to defined gradients of compounds. Mass spectrometry-based metabolite analysis can give further insights into important metabolic signatures of this activity, and $16 \mathrm{~S}$ amplicon sequencing can be used to monitor changes in the microbial community in response to these parameters. Subsequent growth-based assays with isolates from a given microbial enrichment culture can be used to measure isolate fitness and isolate gene fitness in response to the same gradients of compounds in which the enrichment was cultivated. Through measuring metabolic activity, microbial community structure, isolate fitness, and gene fitness in the context of gradients of environmentally relevant parameters, we can build models that link gene-, microbe-, and metabolism-specific fitness to environmental context (Figure 2). Through such workflows, environmental microbiologists now are able to re-array and reconstitute the purified organic and inorganic components of microbial ecosystems at an unprecedented scale and speed.

\section{Toward multidimensional measurements}

Microbes rely on both organic and inorganic cofactors and nutrients and live in complex multidimensional gradients of beneficial, neutral, and toxic compounds ${ }^{12,13}$. Microbial niche space is often viewed as an n-dimensional matrix in which antimetabolites, carbon sources, and essential nutrients influence the ability of a microorganism

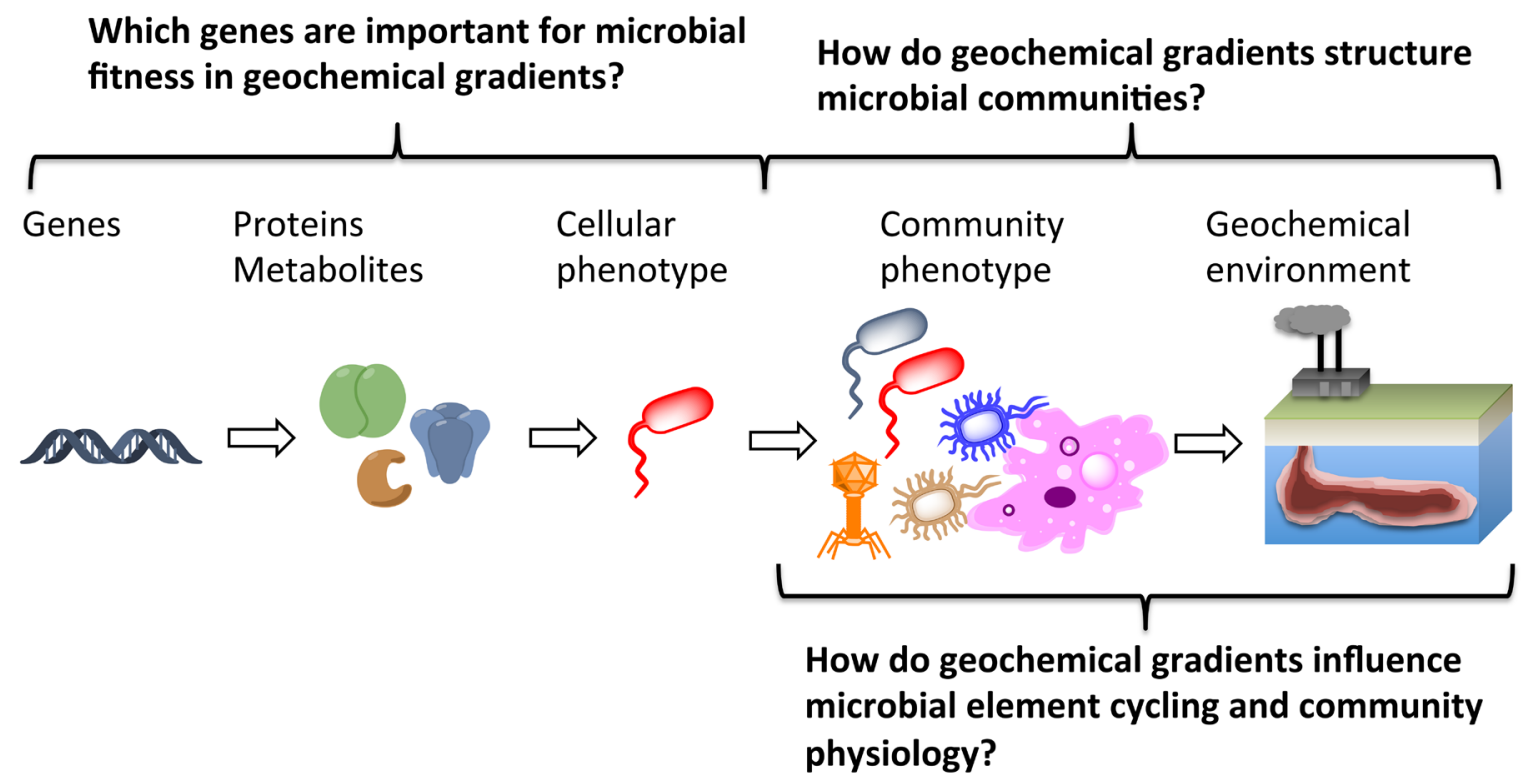

Figure 1. Understanding mechanisms whereby microorganisms survive in geochemical gradients is a central goal of environmental microbiology. Understanding mechanisms whereby microorganisms survive in geochemical gradients is a central goal of environmental microbiology. 


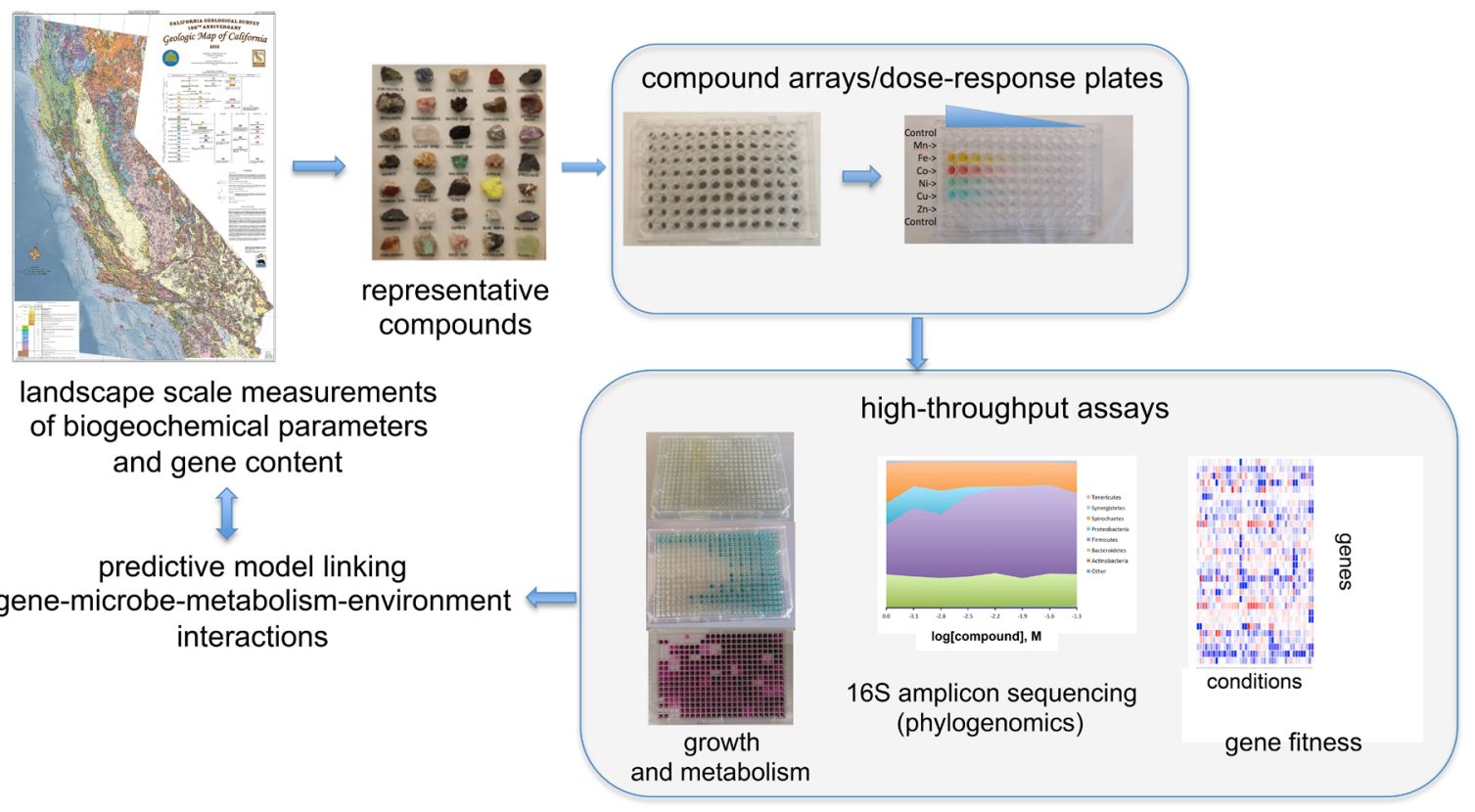

Figure 2. High-throughput cultivation pipelines can be used to evaluate gene-microbe-metabolism fitness in response to gradients of naturally occurring inorganic compounds. Measurements of metal content across rock, soil, and water samples can be obtained, and landscape-scale elemental maps can be constructed. Mineral samples and metal ions can be arrayed in microplates, and taggedtransposon pool assays, $16 \mathrm{~S}$ amplicon sequencing, and metabolism-specific colorimetric assays can be employed to quantify the influence of concentrations of various metals on gene-microbe-metabolism fitness. Linking landscape-scale measurements of geochemistry to highthroughput laboratory measurements of microbial activity in response to geochemistry will enable higher-resolution biogeochemical models.

or microbial community to grow and survive ${ }^{13,14}$. Thus, only by altering the concentrations of multiple inorganic or organic compounds in a massively parallel, high-throughput cultivation platform can we gain a quantitative bottom-up picture of gene-microbe-metabolism-environment interactions. Several highthroughput approaches developed in the biomedical sciences can be applied to problems in environmental microbiology, including high-throughput screens to identify inhibitory compounds, dose-response microplate assays to quantify the inhibitory potency of compounds, checkerboard synergy assays to evaluate non-linear interactions between compounds, and leave-one-out assays to evaluate formulation potencies ${ }^{8,15}$. However, most of the compounds used in the biomedical industry (for example, drugs) are not environmentally relevant. To address this shortfall, we have begun to array metals and other inorganic compounds such as in an "80 metals plate" (Table 1) to create compound collections that more accurately capture the microbial stressors present in the environment. This arrayed compound collection can be serially diluted and added to microbial cultures to determine inhibitory concentrations such as minimal inhibitory concentration (MIC) or the concentration required to inhibit $50 \%$ of control growth $\left(\mathrm{IC}_{50}\right)$. By varying the inoculum, respiratory substrates, and other parameters, experimentalists can gain insights into how other dimensions of the environment influence the inhibitory potency of these inorganic ions on gene-microbe-metabolism fitness.
Microbes know bioinorganic chemistry better than chemists do

Organic life exists and evolves in a matrix of both organic and inorganic compounds. One indelible mark of this evolutionary history consists of the diverse metallocofactors incorporated into enzymes that enable chemistry impossible for catalysts composed solely of $\mathrm{C}, \mathrm{H}, \mathrm{N}, \mathrm{O}, \mathrm{P}$, and $\mathrm{S}^{16}$. High concentrations of metals are toxic to cells, and many metals also serve no catalytic role. Therefore, resistance mechanisms to metals have evolved. Metals are toxic to microorganisms because of their redox activity and because antimetabolic metals can compete with cofactor metals for binding to biological ligands and proteins ${ }^{17}$. Not surprisingly, microorganisms have evolved mechanisms for coping with metal stress, and these mechanisms vary by microorganism, metabolic state, or metal and are different depending on the metal concentration ${ }^{16,18}$. As an example, iron and its interactions with other transition metals and microbial cells are fairly well studied. Iron is an essential metal for a variety of metalloproteins. Under limiting concentrations of iron, other transition metals can interfere with high-affinity iron uptake systems and metalloregulatory proteins ${ }^{19}$, but at higher concentrations, some transition metals are toxic because of their ability to catalyze the production of reactive oxygen species ${ }^{20}$. Thus, the mechanism of toxicity and the mechanisms of resistance will be different depending on the concentrations of the metals. Very few studies systematically evaluate metal toxicity under both excess and 
Table 1. 80 metals plate.

\begin{tabular}{|c|c|}
\hline Compound name & $\begin{array}{l}\text { Stock } \\
\text { concentration, } \mathrm{mM}\end{array}$ \\
\hline Sodium sulfate & 1,000 \\
\hline Sodium sulfite & 1,000 \\
\hline Sodium selenate & 1,000 \\
\hline Sodium selenite & 1,000 \\
\hline Sodium perchlorate & 1,000 \\
\hline Sodium chlorate & 1,000 \\
\hline Sodium silicate & 1,000 \\
\hline Sodium nitrate & 1,000 \\
\hline Sodium nitrite & 100 \\
\hline Sodium phosphate & 1,000 \\
\hline Sodium phosphite & 1,000 \\
\hline Sodium hypophosphite & 1,000 \\
\hline Sodium fluorophosphate & 1,000 \\
\hline Sodium arsenate & 1,000 \\
\hline Sodium m-arsenite & 1,000 \\
\hline $\begin{array}{l}\text { Ferric-nitrilotriacetic } \\
\text { acid (Ferric-NTA) }\end{array}$ & 10 \\
\hline Zinc-NTA & 10 \\
\hline Copper-NTA & 10 \\
\hline Potassium chromate & 1,000 \\
\hline Sodium molybdate & 1,000 \\
\hline Sodium tungstate & 1,000 \\
\hline Sodium bromate & 1,000 \\
\hline Sodium thiosulfate & 1,000 \\
\hline Sodium chloride & 2000 \\
\hline Sodium bromide & 1,000 \\
\hline Sodium iodide & 1,000 \\
\hline Sodium fluoride & 1,000 \\
\hline Lithium chloride & 1,000 \\
\hline Potassium chloride & 1,000 \\
\hline Rubidium chloride & 1,000 \\
\hline Cesium chloride & 1,000 \\
\hline Magnesium chloride & 1,000 \\
\hline Calcium chloride & 1,000 \\
\hline Strontium chloride & 1,000 \\
\hline $\begin{array}{l}\text { Barium chloride } \\
\text { dihydrate }\end{array}$ & 10 \\
\hline Chromium(III) chloride & 10 \\
\hline Manganese(II) chloride & 10 \\
\hline Ferric chloride & 100 \\
\hline Cobalt chloride & 10 \\
\hline Nickel(II) chloride & 10 \\
\hline Copper(II) chloride & 10 \\
\hline
\end{tabular}

\begin{tabular}{|c|c|}
\hline Compound name & $\begin{array}{l}\text { Stock } \\
\text { concentration, } \mathrm{mM}\end{array}$ \\
\hline Zinc chloride & 10 \\
\hline Aluminum chloride & 10 \\
\hline Cadmium chloride & 10 \\
\hline Thallium(I) acetate & 10 \\
\hline Cerium(III) chloride & 1,000 \\
\hline Europium(III) chloride & 100 \\
\hline $\begin{array}{l}\text { Ethylenediamine-N,N'- } \\
\text { disuccinic acid (EDTA) }\end{array}$ & 500 \\
\hline NTA & 500 \\
\hline Chromium-NTA & 10 \\
\hline Nickel-NTA & 10 \\
\hline Ammonium chloride & 1,000 \\
\hline $\begin{array}{l}\text { Hydroxylamine } \\
\text { hydrochloride }\end{array}$ & 1,000 \\
\hline Vanadium chloride & 10 \\
\hline $\begin{array}{l}\text { Ferrous ammonium } \\
\text { sulfate }\end{array}$ & 10 \\
\hline Beryllium sulfate & 1,000 \\
\hline Gallium(III) chloride & 100 \\
\hline Lead(II) chloride & 10 \\
\hline Sodium cyanide & 100 \\
\hline Sodium pyrophosphate & 100 \\
\hline Sodium metavanadate & 100 \\
\hline Sodium periodate & 100 \\
\hline Sodium iodate & 100 \\
\hline Sodium thiophosphate & 100 \\
\hline Sodium chlorite & 100 \\
\hline Sodium hypochlorite & 10 \\
\hline Potassium tellurate & 1 \\
\hline Silver chloride & 1 \\
\hline $\begin{array}{l}\text { Potassium } \\
\text { hexahydroxoantimonate }\end{array}$ & 10 \\
\hline Gold chloride & 1 \\
\hline Mercury chloride & 10 \\
\hline Platinum(IV) chloride & 10 \\
\hline Palladium(II) chloride & 10 \\
\hline Potassium tellurite & 10 \\
\hline Boric acid & 10 \\
\hline Bismuth chloride & 1 \\
\hline Cobalt-NTA & 10 \\
\hline Manganese-NTA & 10 \\
\hline Cadmium-NTA & 10 \\
\hline Aluminum-NTA & 10 \\
\hline
\end{tabular}

These compounds are arrayed in a 96-well microplate format that can be serially diluted into other microplate formats for high-throughput cultivation of microbial cultures. 
limiting concentrations of essential metals, but by quantifying the toxicity of larger panels of metals under these conditions, we can obtain "structure-activity" information for inorganic compounds and their toxicity against, for example, uptake and efflux systems (Figure 3). A microplate array involving compounds such as the "80 metals plate" described in Table 1 could be serially diluted and used to evaluate the toxicity of many metals simultaneously against microbial isolates, enrichments, and pooled transposon mutants. Metal cations and oxyanions with varying ionic radii, charge, and electron affinity will vary in their interaction with different cellular systems. Only by quantifying the inhibitory potency of these metals under the various conditions under which these different cellular systems are important can we gain insights into how these systems have or have not evolved resistance to various metals. Ultimately, the data obtained through such studies will help geomicrobiologists to infer which metals may have been present in the environment in which a microbe evolved and to quantify the geochemical and genetic parameters that limit the growth of a microbial isolate or community in the environment.

\section{Metal-metabolism interactions}

Metal requirements and toxicity are influenced by the metabolic state of a microorganism. Microorganisms can grow with a range of electron donors, carbon sources, and electron acceptors. All of these metabolisms have unique metal requirements and sensitivities to inorganic antimetabolites and toxins. As such, metals can be selective inhibitors or promoters of different metabolisms. For example, zinc can be more inhibitory of bacteria growing under glucose catabolic conditions versus other carbon sources because zinc inhibits key enzymes in glycolysis ${ }^{21}$. Against respiratory sulfate reduction, monofluorophosphate, molybdate, and perchlorate are all selective inhibitors with varying selectivities, potencies, and modes of inhibition against the central enzymes in the sulfate reduction pathway ${ }^{22}$. Some redox-active metals are more inhibitory of aerobically growing cells than anaerobic cells because they can reduce oxygen to superoxide and catalyze Fenton chemistry. By quantifying the inhibitory or stimulatory potencies of large panels of inorganic compounds against microbial isolates and enrichments carrying out various
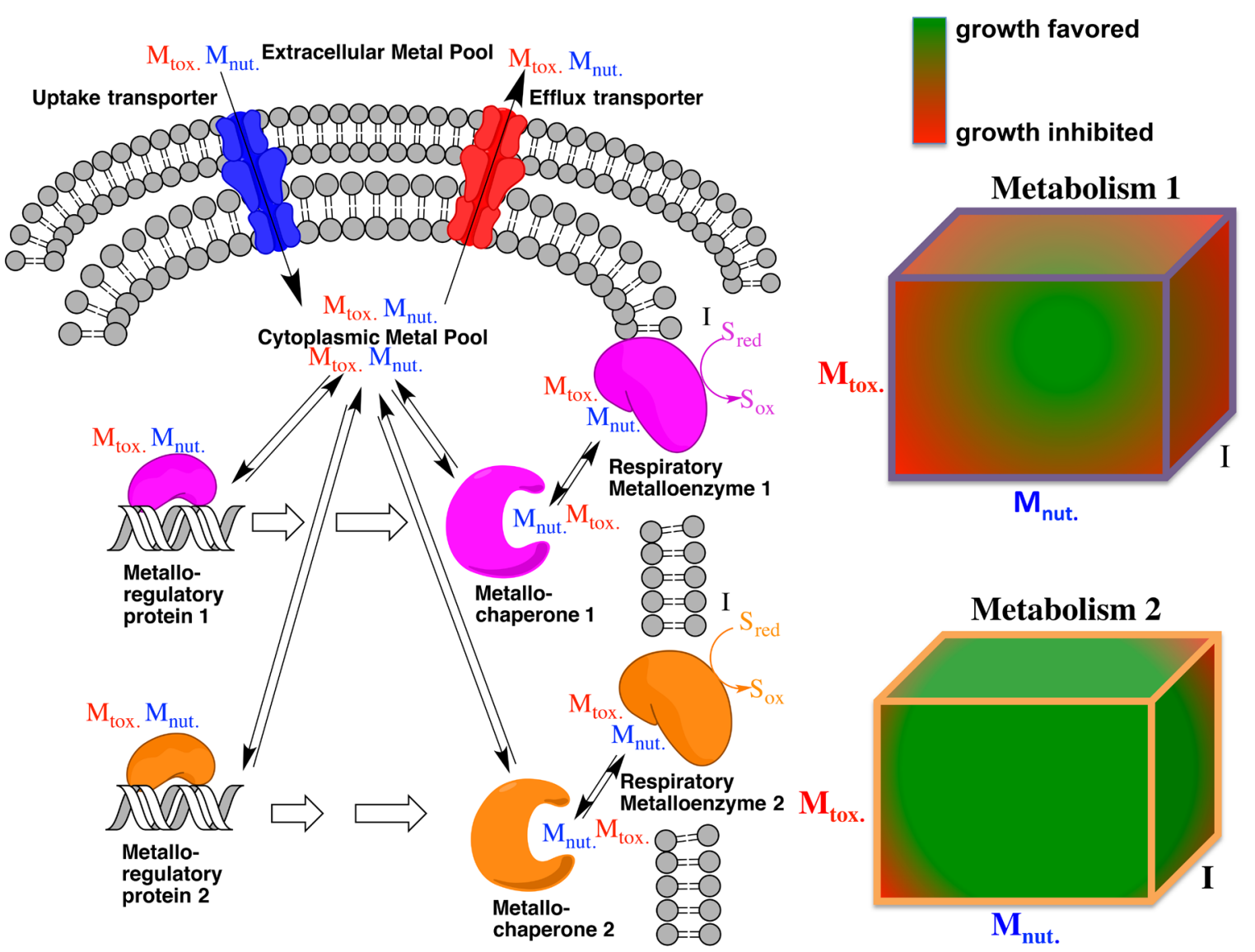

Figure 3. Toxic metals $\left(\mathbf{M}_{\text {tox. }}\right)$ interfere with the metabolism of essential, nutrient metals $\left(\mathbf{M}_{\text {nut. }}\right)$. The influence of a toxic metal will vary depending on the metabolism. For example, metabolism 1 and metabolism 2 could be aerobic respiration, nitrate reduction, sulfate reduction, and photosynthesis. Similarly, other metals (I) can serve as antimetabolic inhibitors of respiratory enzymes, competing with substrate $\left(\mathrm{S}_{\text {red }}\right)$ for binding and turnover to product $\left(\mathrm{S}_{\mathrm{ox}}\right)$. Depending on the inhibitory potency of the toxic metal $\left(\mathrm{M}_{\text {tox }}\right)$, the requirements of the essential metal $\left(\mathrm{M}_{\text {nut }}\right)$, and the inhibitory potency of a respiratory inhibitor (I), different metabolisms will have different environmental ranges in response to metal gradients. 
metabolic activities selective compounds can be identified and the degree of their selectivity quantified. Quantification of these tipping points will improve biogeochemical reactive transport models that incorporate predictions of microbial metabolic activities.

Optimism for the future: identifying novel antimetabolites as predictors of ecosystem function and environmental engineering strategies

Multidimensional microbiology is poised to become the norm in the 21 st century. Alongside rapidly improving computational and analytical tools, high-throughput microbial physiology will enable massively parallel measurements of microbial fitness in complex gradients of environmentally relevant conditions. Rarefaction curves from genome sequencing datasets imply that the genetic diversity of life is not infinite ${ }^{23}$, nor is the elemental composition of biosphere. From this perspective, the "infinite and subtle complexity" of the natural world has more to do with the fractal complexity of natural gradients, heterogeneous mixtures in soil, complex water currents, and the corresponding conglomerate of microbial activity in this geochemical milieu. Thus, although we may not reach a comprehensive and flawless model of biogeochemical processes on Earth from bottom-up measurements of microbial fitness and physiology, we are likely to greatly increase the resolution of our models through careful, high-throughput experimentation.

\section{Competing interests}

The authors declare that they have no competing interests.

\section{Grant information}

This work was funded by the UC Berkeley Energy Biosciences Institute and ENIGMA. ENIGMA is a Scientific Focus Area Program supported by the U. S. Department of Energy, Office of Science, Office of Biological and Environmental Research and Genomics:GTL Foundational Science, through contract DE-AC02-05CH11231 between Lawrence Berkeley National Laboratory and the U. S. Department of Energy.

The funders had no role in study design, data collection and analysis, decision to publish, or preparation of the manuscript.
1. Adams D: The More Than Complete Hitchhiker's Guide: Complete \& Unabridged. 1989. Reference Source

2. Smith DB, Cannon WF, Woodruff LG, et al:: Geochemical and Mineralogical Data for Soils of the Conterminous United States. U.S. Geological Survey Data Series 801, 2013; 19: 1-26.

Reference Source

3. Ellefsen KJ, Smith DB, Horton JD: A modified procedure for mixture-model clustering of regional geochemical data. Appl Geochem. 2014; 51 315-326.

Publisher Full Text

4. Isaacman G, Wilson KR, Chan AW, et al:: Improved resolution of hydrocarbon structures and constitutional isomers in complex mixtures using gas chromatography-vacuum ultraviolet-mass spectrometry. Anal Chem. 2012; 84(5): 2335-42.

PubMed Abstract | Publisher Full Text

5. $\quad F$ Markowitz VM, Chen IA, Chu K, et al.: Ten years of maintaining and expanding a microbial genome and metagenome analysis system. Trends Microbiol. 2015; 23(11): 730-41.

PubMed Abstract | Publisher Full Text | F1000 Recommendation

6. $\quad F$ Wang DZ, Kong LF, Li YY, et al.: Environmental Microbial Community Proteomics: Status, Challenges and Perspectives. Int J Mol Sci. 2016; 17(8): pii: E1275.

PubMed Abstract | Publisher Full Text | Free Full Text | F1000 Recommendation

7. Carlson HK, Stoeva MK, Justice NB, et al:: Monofluorophosphate is a selective inhibitor of respiratory sulfate-reducing microorganisms. Environ Sci Technol. 2015; 49(6): 3727-36

PubMed Abstract | Publisher Full Text

8. $\quad \mathrm{F}$ Tietjen $\mathrm{K}$, Drewes M, Stenzel K: High throughput screening in agrochemica research. Comb Chem High Throughput Screen. 2005; 8(7): 589-94. PubMed Abstract | Publisher Full Text | F1000 Recommendation

9. Wetmore KM, Price MN, Waters RJ, et al.: Rapid quantification of mutant fitness in diverse bacteria by sequencing randomly bar-coded transposons. mBio. 2015; 6(3): e00306-15.

PubMed Abstract | Publisher Full Text | Free Full Text

10. Deutschbauer A, Price MN, Wetmore KM, et al.: Evidence-based annotation of gene function in Shewanella oneidensis MR-1 using genome-wide fitness profiling across 121 conditions. PLoS Genet. 2011; 7(11): e1002385. PubMed Abstract | Publisher Full Text | Free Full Text

11. Skerker JM, Leon D, Price MN, et al.: Dissecting a complex chemical stress: chemogenomic profiling of plant hydrolysates. Mol Syst Biol. 2013; 9: 674. PubMed Abstract | Publisher Full Text | Free Full Text
12. Emerson D, Breznak JA: The response of microbial populations from oil-brine contaminated soil to gradients of $\mathrm{NaCl}$ and sodium $p$-toluate in a diffusion gradient chamber. FEMS Microbiol Ecol. 1997; 23(4): 285-300. Publisher Full Text

13. $\mathrm{F}$ Eisenhauer $\mathrm{N}$, Schulz W, Scheu S, et al:: Niche dimensionality links biodiversity and invasibility of microbial communities. Funct Ecol. 2013; 27(1): 282-288.

Publisher Full Text | F1000 Recommendation

14. Wimpenny JW: Spatial order in microbial ecosystems. Biological Reviews. 1981; 56(3): 295-342. Publisher Full Text

15. F Arkin MR, Ang KK, Chen S, et al.: UCSF Small Molecule Discovery Center: innovation, collaboration and chemical biology in the Bay Area. Comb Chem High Throughput Screen. 2014; 17(4): 333-42.

PubMed Abstract | Publisher Full Text | F1000 Recommendation

16. Crichton R: Biological Inorganic Chemistry. 1st ed. Amsterdam: Elsevier; 2008; $1-383$.

Reference Source

17. Outten FW, Twining BS: Metal homeostasis: an overview. 2007. Reference Source

18. F Gadd GM: Metals, minerals and microbes: geomicrobiology and bioremediation. Microbiology. 2010; 156(Pt 3): 609-43. PubMed Abstract | Publisher Full Text | F1000 Recommendation

19. F Lee JW, Helmann JD: Functional specialization within the Fur family of metalloregulators. Biometals. 2007; 20(3-4): 485-99. PubMed Abstract | Publisher Full Text | F1000 Recommendation

20. $\mathrm{F}$ Braud A, Hoegy $F$, Jezequel $K$, et al.: New insights into the metal specificity of the Pseudomonas aeruginosa pyoverdine-iron uptake pathway. Environ Microbiol. 2009; 11(5): 1079-91.

PubMed Abstract | Publisher Full Text | F1000 Recommendation

21. F Ong CL, Walker MJ, McEwan AG: Zinc disrupts central carbon metabolism and capsule biosynthesis in Streptococcus pyogenes. Sci Rep. 2015; 5: 10799. PubMed Abstract | Publisher Full Text | Free Full Text | F1000 Recommendation

22. Carlson HK, Kuehl JV, Hazra AB, et al.: Mechanisms of direct inhibition of the respiratory sulfate-reduction pathway by (per)chlorate and nitrate. ISME J. 2015; 9(6): 1295-305. PubMed Abstract | Publisher Full Text | Free Full Text

23. $\mathrm{F}$ Land $\mathrm{M}$, Hauser $\mathrm{L}$, Jun SR, et al.: Insights from 20 years of bacterial genome sequencing. Funct Integr Genomics. 2015; 15(2): 141-61. PubMed Abstract | Publisher Full Text | Free Full Text | F1000 Recommendation 


\section{Open Peer Review}

\section{Current Peer Review Status:}

\section{Editorial Note on the Review Process}

Faculty Reviews are review articles written by the prestigious Members of Faculty Opinions. The articles are commissioned and peer reviewed before publication to ensure that the final, published version is comprehensive and accessible. The reviewers who approved the final version are listed with their names and affiliations.

\section{The reviewers who approved this article are:}

\section{Version 1}

\section{David Emerson}

Ocean Microbiome \& Blue Biotechnology Center, Bigelow Laboratory for Ocean Sciences, East Boothbay, ME, USA

Competing Interests: No competing interests were disclosed.

\section{Bin Cao}

School of Civil and Environmental Engineering and Singapore Centre for Environmental Life Sciences Engineering, Nanyang Technological University, Singapore, Singapore

Competing Interests: No competing interests were disclosed.

\section{Comments on this article}

\section{Version 1}

\section{Reader Comment 06 Jul 2017}

Elena Angela Lusi, 1. St Vincent Health Care Group, University College of Dublin, Ireland., Ireland

To the Authors,

Thank you for this beautiful piece of Science.

Recently, nickel-resistant bacteria have been isolated from the first time in human gut.

https://doi.org/10.1016/j.nmni.2017.06.001

While the role of heavy resistant bacteria in the environment has been extensively studied, the impact of these bacteria in human health needs further investigations.

Elena Angela Lusi 
Competing Interests: no conflict of interest to declare.

The benefits of publishing with F1000Research:

- Your article is published within days, with no editorial bias

- You can publish traditional articles, null/negative results, case reports, data notes and more

- The peer review process is transparent and collaborative

- Your article is indexed in PubMed after passing peer review

- Dedicated customer support at every stage

For pre-submission enquiries, contact research@f1000.com 